American Journal of Agricultural and Biological Sciences 7 (1): 1-16, 2012

ISSN 1557-4989

(C) 2012 Science Publications

\title{
An Innovative Farm Scale Biogas/Composting Facility for a Sustainable Medium Size Dairy Farm
}

\author{
A.E. Ghaly and M. Al hattab \\ Department of Process Engineering and Applied Science, \\ Dalhousie University Halifax, Nova Scotia, Canada
}

\begin{abstract}
Approach: The amount of energy related costs as a portion of the total farm operating cost can be as high as $29 \%$ and the continuing increase of the real cost of energy related farm input has been one of the major factors impacting the cost of agricultural production. However, agricultural has the potential of replacing some of the purchased energy in the form of fossil fuels, commercial fertilizer and field production of animal feed with bioenergy and organic fertilizer from onsite renewable biomass such as animal manure in order to economically and environmentally sustain it. The aim of this study was to develop an innovative energy efficient pilot scale anaerobic digester composting facility. Methodology: A solid/liquid manure separator farm scale anaerobic digester and composting facility for a medium sized dairy farm were designed, constructed and tested. In order to make the anaerobic digestion economically viable under Canadian climatic conditions, the design, installation and operation of the system were based on advantages gained from the digester as a component of the total farm management system. In addition to the biogas production, benefits related to manure handling and storage, environmental quality improvement through odor control and water pollution reduction, fertilizer recovery and water recycling, were considered. Results: The layout of the farm was modified to provide solutions for four environmental problems related to: disposal of milkhouse wastes and overflow from the manure storage facility into the fire pond. The system possesses high energy conversion efficiency at relatively low capital cost and reduced labour requirement and has indirect energy ramifications through the production of organic fertilizer (compost) to replace expensive and energy consuming commercial fertilizer as well as the production of bioenergy (biogas) which will reduce the demand for energy. The overflow from the system (purified water) can be recycled for cleaning the barn, thereby reducing the costs of water use and manure storage facilities on one hand and eliminating pollution problems associated with manure storage and disposal on the other hand. Conclusion: The use of dairy waste as a source of energy and fertilizer resulted in a saving of $6289 \mathrm{~kg}$ of fertilizer at a cost of $\$ 17925$ annually and additional saving of \$20 547 on energy use.
\end{abstract}

Key words: Anaerobic digestion, farm scale, solid/liquid manure separator, temperature, moisture content, $\mathrm{pH}$, micronutrient, eliminating pollution problems, consuming commercial fertilizer, increasing rapidly, provide solutions

\section{INTRODUCTION}

The world population is growing and the demand for food is increasing rapidly (Isaac and Van Vuuren, 2009). To meet the ever increasing food demand, modern large scale farm operations have become dependent upon a prodigious consumption of energy derived mostly from fossil fuels. These sources of energy which we rely on for $80 \%$ of our needs are rapidly depleting and energy price and security of supply are affecting agricultural production cost worldwide (Shafiee and Topal, 2007).
The amount of energy related costs as a proportion of the total farm operating costs can be as high as $29 \%$ in areas where field crop production predominates. Thus, the increase in the real cost of energy and energy related inputs has been one of the major factors impacting the cost of the agricultural production (Nguyen et al., 2010; Bot, 2001).

However, agriculture has the potential for replacing some of the purchased energy in the form of fossil fuels, commercial fertilizer and field produced animal feed with bioenergy, organic fertilizer and animal feed

Corresponding Author: Abdel Ghaly, Department of Process Engineering and Applied Science, Dalhousie University, Halifax, Nova Scotia, Canada. Tel: (902) 494-6015 
from on-site renewable biomass in order to economically and environmentally sustain itself (Lunnan, 1997). Biogas production from biomass sources could be the manures from livestock and poultry operations Fig. 1. Fuels from these biomass materials could be used for space and water heating of farm houses and animal shelters, grain drying and as fuels for heating greenhouses, with their high energy demands in cold Canadian weather. The latter is particularly important if Canada is to reduce its imports of horticultural off-season crops. Recovery of organic fertilizers and animal feeds will not only reduce the operating costs of agricultural operations but will also help sustain the environment in which it operates and relies upon. While the energy, fertilizer and feed required to operate the farm sector are theoretically available in adequate quantities, it is yet the economics and management problems associated with the introduction of a new technology and matching the supply with the demand.

The main aim of this study was to develop an innovative, energy efficient pilot scale anaerobic digestion-composting facility capable of producing biogas (as an energy source) and compost (as organic fertilizer) from dairy manure while minimizing the pollution potential of these wastes. To overcome the economic difficulties usually associated with new technologies, the system must be treated as an integral part of the farm management scheme.

\section{BACKGROUND}

Dairy waste: Dairy manure refers to the fecal $(70 \%)$ and urinary $(30 \%)$ excrements of dairy cattle. When beddings, rain, soil, hair, waste feed materials, milkhouse waste and washing water are added to manure, the term dairy waste is generally used (Shi et al., 1999). In terms of volume, dairy cows produce about $82.4 \mathrm{~L}$ of waste per $1000 \mathrm{~kg}$ live weight per day. Generally, an average dairy cow will produce between 14.2 and $18.3 \mathrm{t}$ of faces and urine per year (Loehr, 1984).

Waste resulting from dairy production can be detrimental to the environment and a hazard to the health and safety of humans and livestock (Arvanitoyannis and Kassaveti, 2008). Contamination of surface water can result from direct dumping of manure into streams and lakes, runoff from stockpiles, overflow from manure storages, surface runoff following application of manure on frozen and/or sloppy land, excessive application of manure when crops cannot fully utilize it, long term application of manure, direct access of cows to surface waters and direct adsorption of air-borne waste particles by nearby bodies of water (Dabrowski et al., 2002; Mawdsley et al., 1995). Ground water contamination may result from percolation after excessively high manure application and seepage from waste stabilization lagoons constructed on porous soils (Centner et al., 2006; Almasri and Kaluarachchi, 2004; Ghaly and Singh, 1991). Dairy manure is also a source of numerous pathogens that infect both human and livestock. Pathogens that are known to have been spread through animal manure include Salmonella, E. coli, Campylobacter, Leptospira, Cryptosporidium, Giardia and other parasitic bacteria and nematodes (Cliver, 2009; Albihn and Vinneras, 2007).

The biodegradation of organic components of waste by microbes exerts an oxygen demand leading to the depletion of the dissolved oxygen content of the contaminated water which eventually would no longer be able to support aquatic life and becomes septic and unpleasant in color and smell (Anderson and Quartermaine, 1998). Nitrogen in form of nitrate can be a source of problems to babies and young animals (Ellis et al., 1998). The lower acid content of infant intestinal tract often permits the growth of denitrifying bacteria which reduces the ingested nitrate into nitrite to be absorbed into the blood stream. Since nitrite has greater affinity for haemoglobin than oxygen, the later is displaced in the blood system denying the body of essential oxygen. Extreme cases of oxygen deprivation results in asphyxiation with the body of the victim turning blue, a phenomenon often referred to as "blue baby syndrome" or "methanoglobinemia" (Mishra and Patel, 2007; Ghaly and Singh, 1991).

Air pollution is another dairy manure problem. Under uncontrolled anaerobic conditions, biological breakdown of stored dairy manure takes place. Many volatile compounds and intermediates are produced which escape and cause odour problems (Melse and Timmerman, 2009). More than fifty compounds consisting of acids, alcohols, amines, carbonlys, esthers, sulphides, mercaptans, nitrogen and other gases have been identified in air associated with anaerobic decomposition of animal waste (Dammgen and Hutchings, 2007). Ammonia, methane and hydrogen sulphides are produced in easily detectable amounts (Ni et al., 2000).

Dairy manure can be utilized for the production of value added products while reducing or eliminating environmental health problems.

The organic components of manure which determine its potential as a source of animal feed include: carbohydrates, crude protein, fat and gross energy are shown in Table 1 (El Jalil et al., 2001; El Boushy, 1991). 
Am. J. Agri. \& Biol. Sci., 7 (1): 1-16, 2012

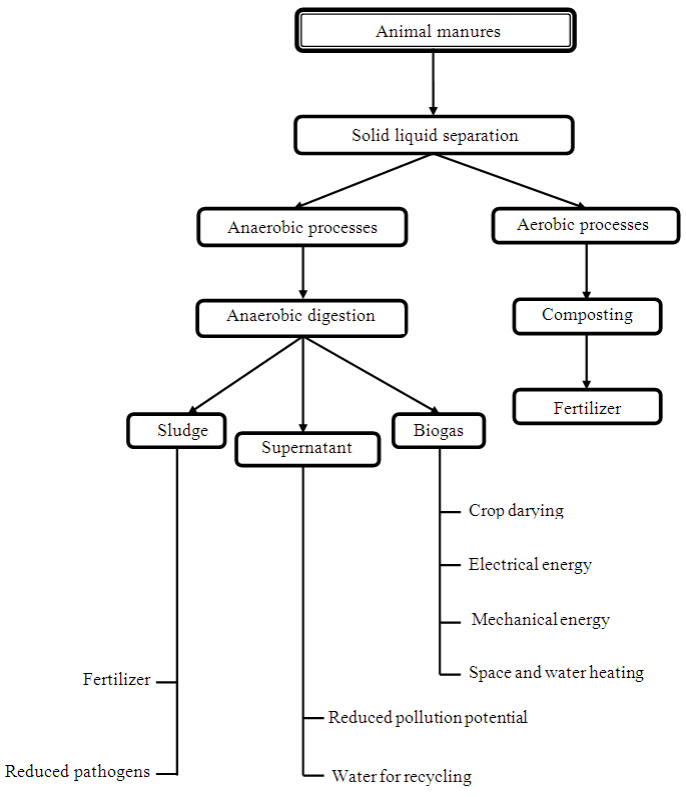

Fig. 1: Potential uses of end products from anaerobic digestion/composting

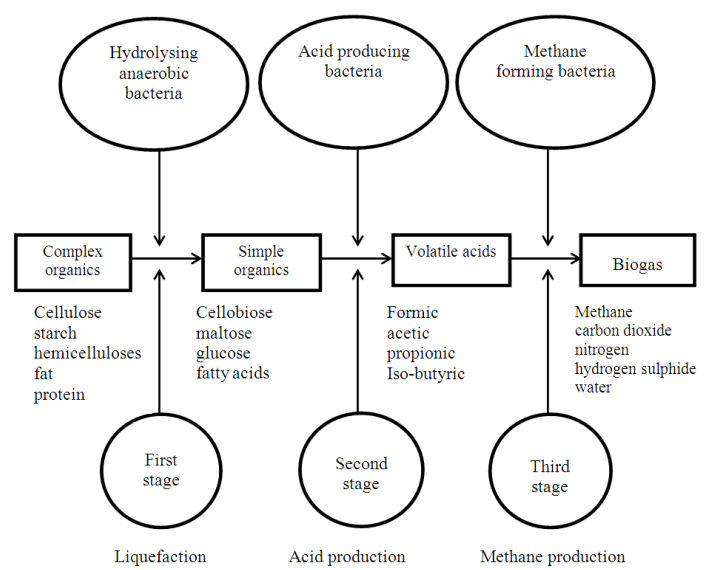

Fig. 2: Three stage anaerobic digestion process

Table 1: Organic nutrient content of dairy manure

\begin{tabular}{lr}
\hline Parameter & Value \\
\hline Crude protein (\%) & 13.20 \\
True protein & 12.60 \\
Non-protein & 0.60 \\
Crude fibre (\%) & 11.50 \\
Neutral detergent fibre & 7.60 \\
Acid detergent fibre & 3.90 \\
Carbohydrate (\%) & 740.00 \\
Cellulose & 23.40 \\
Hemi-celulose & 19.30 \\
Lignin & 14.90 \\
Cell walls & 6.20 \\
Sugar & 10.20 \\
Fat $(\%)$ & 1.70 \\
Gross energy (MJ/kg TS) & 15.90 \\
\hline
\end{tabular}

Table 2: Inorganic mineral content of dairy manure

\begin{tabular}{|c|c|c|c|}
\hline \multirow[b]{2}{*}{ Type } & \multirow[b]{2}{*}{$\begin{array}{l}\text { Production } \\
\text { (kg } 1000 \mathrm{~kg}^{-1} \text { live wt.) }\end{array}$} & \multicolumn{2}{|l|}{ Amount } \\
\hline & & $\mathrm{kg} / \mathrm{t}$ & $\mathrm{mg} / \mathrm{L}$ \\
\hline Total Nitrogen & 0.450 & 5.900 & 5840 \\
\hline Ammonium Nitrogen & 0.079 & & 1750 \\
\hline Potassium & 0.290 & 5.000 & 4950 \\
\hline Calcium & 0.160 & 2.800 & 2772 \\
\hline Chloride & 0.130 & 6.800 & 6732 \\
\hline Phosphorus & 0.094 & 1.100 & 1089 \\
\hline Magnesium & 0.071 & 6.300 & 1089 \\
\hline Sodium & 0.051 & 3.700 & 6237 \\
\hline Sulphur & $1.90 \times 10^{-6}$ & 0.145 & 3663 \\
\hline Manganese & $1.80 \times 10^{-6}$ & 0.210 & 144 \\
\hline Zinc & $1.29 \times 10^{-6}$ & 1.170 & 208 \\
\hline Iron & $7.19 \times 10^{-7}$ & 0.049 & 1158 \\
\hline Boron & $4.59 \times 10^{-7}$ & 0.031 & 49 \\
\hline Copper & $2.89 \times 10^{-7}$ & 0.018 & 31 \\
\hline Nickel & $7.49 \times 10^{-8}$ & 0.005 & 5 \\
\hline Molybdenum & $3.09 \times 10^{-9}$ & & 14 \\
\hline Cadmium & & 1.050 & 1040 \\
\hline Barium & & 0.016 & 16 \\
\hline Cobalt & & 0.014 & 14 \\
\hline Strontium & & 0.009 & 9 \\
\hline Chromium & & 0.007 & 7 \\
\hline
\end{tabular}

Dairy manure also include inorganic minerals including nitrogen, phosphorus, potassium and other macro and micro plant nutrients Table 2 that makes it attractive as a fertilizer (Kuligowski et al., 2010; Schroder, 2005; Oudendag and Luesink, 1998). In addition, dairy manure can be digested under anaerobic conditions for the production of biogas for use as a fuel and sludge for use as organic fertilizer (El-Mashad and Zhang, 2010; Batzias et al., 2005; Sarapatka, 1994).

Anaerobic digestion: Anaerobic digestion is a complex microbiological process in which many different facultative and anaerobic microorganisms are involved in an interdependence (symbiosis) relationship (Ghaly and Echiegu, 1993). A three stage scheme Fig. 2 has been traditionally used to describe the anaerobic digestion process (Ghaly, 1989). In the first stage, one group of microbes hydrolyses, liquefies and ferments the complex organics to simpler, soluble compounds using extracellular enzymes excreted to the medium. In the second stage, the hydrolysed substrate can pass through the cell walls and be utilised by another group of microbes that are referred to as acid-formers (acidogenes) and consist of facultative and obligate anaerobic microbes. Some acidogenic microbes that have been isolated from anaerobic digesters include: Desulfobulbus spp., $\quad$ Desulfovibrio spp., Pseudomonas spp., Clostridium spp., Bacteroides spp., Ruminococcus spp., Peptococcus anaerobes, Bifidobacterium spp., Corynebacterium spp., Lactobacillus, Actinomyces, Staphylococcus and Escherichia coli (Zhao et al., 2008). Table 3 shows some of the organic acid-producing microbes along 
with the products formed. The predominant species are gram-negative, spore-forming bacilli which can produce acetic and butyric acids as well as carbon dioxide and hydrogen (Grady and Lim, 1980). The acid formers are usually fairly resilient and are better able to withstand sudden changes in temperature and $\mathrm{pH}$ than the other group of microbes (Meynell, 1978). They serve two important functions: (a) provide the food for the methane-formers and (b) utilise dissolved oxygen that is toxic to the 'methane-formers'. In the third stage, the methane-formers, (methanogens) convert the organic acids to methane. These are obligate anaerobes and as such dissolved oxygen $(0.01 \mathrm{ppm})$ is toxic to them (Imlay, 2002).

Among the genus of methanogens are: Methanobacterium (a non spore-forming rod), Methanosarcina (a non spore-forming coccus in pockets of eight), Methanococcus (a nonspore-forming rod), Methanosarcina (a nonspore-forming coccus) and Methanobacillus (a spore-forming rod) (Marchesi et al., 2001). Table 4 shows some of the species of methanogens involved in anaerobic digestion.

Table 3: Some organic acid-producing microbes

\begin{tabular}{|c|c|c|c|}
\hline Microbe & $\mathrm{pH}$ & $\begin{array}{l}\text { Temperature } \\
\left({ }^{\circ} \mathrm{C}\right)\end{array}$ & Products \\
\hline Bacillus cereus & 5.2 & $25-35$ & Acetic, lactic \\
\hline Bacillus knelfelkampi & $5.2-8.0$ & $25-35$ & Acetic, lactic \\
\hline Bacillus megaterium & $5.2-7.5$ & $28-35$ & \\
\hline Bacteriodes succinogens & $5.2-7.5$ & $25-35$ & Acetic, succinic \\
\hline $\begin{array}{l}\text { Clostridium } \\
\text { carnofoetidum }\end{array}$ & $5.0-8.5$ & $25-37$ & \\
\hline $\begin{array}{l}\text { Clostridium } \\
\text { cellobioparus }\end{array}$ & $5.0-8.5$ & $36-38$ & $\begin{array}{l}\text { Formic, acetic, lactic, } \\
\text { Ethanol, carbon }\end{array}$ \\
\hline Clostridium dissolvens & $5.0-8.5$ & $35-51$ & Formic, acetic, lactic \\
\hline $\begin{array}{l}\text { Clostridium } \\
\text { thermocellulaseum }\end{array}$ & $5.0-8.5$ & $55-65$ & $\begin{array}{l}\text { Formic, acetic, } \\
\text { Lactic, succinic }\end{array}$ \\
\hline $\begin{array}{l}\text { Pseudomonas formicans } \\
\text { Ruminocossus }\end{array}$ & - & $33-42$ & $\begin{array}{l}\text { Formic, acetic, lactic, } \\
\text { Succinic, ethanol }\end{array}$ \\
\hline Flavefaciens succinic & - & $33-38$ & Formic, acetic, \\
\hline
\end{tabular}

Table 4: Some organisms involved in the methane formation reactions

\begin{tabular}{ll}
\hline Organics & Reactions \\
\hline $\begin{array}{l}\text { Methanobacterium } \\
\text { soehngenii }\end{array}$ & $\mathrm{CH}_{3} \mathrm{COOH} \rightarrow \mathrm{CH}_{4}+\mathrm{CO}_{2}$ \\
$\begin{array}{l}\text { Methanococcus mazei } \\
\text { Methanosarcina methanica }\end{array}$ & \\
Methanosarcina barkeri & \\
\hline $\begin{array}{l}\text { Methanobacterium } \\
\text { propionicum }\end{array}$ & \\
$\begin{array}{l}\text { Methanococcus mazei } \\
\text { 5CO }\end{array}$ & $4 \mathrm{CH}_{3} \mathrm{CH}_{2} \mathrm{COOH}+2 \mathrm{H}_{2} \mathrm{O} \rightarrow 7 \mathrm{CH}_{4}+$ \\
$\begin{array}{l}\text { Methanosarcina methanica } \\
\text { 5CH}+3 \mathrm{CO}_{2}\end{array}$ & $2 \mathrm{CH}_{3}\left(\mathrm{CH}_{2}\right)_{2} \mathrm{COOH}+2 \mathrm{H}_{2} \mathrm{O} \rightarrow$ \\
$\begin{array}{l}\text { Methanobacterium } \\
\text { suboxydans }\end{array}$ & \\
\hline $\begin{array}{l}\text { Organism not defined } \\
\text { Methanobacterium omelinanskii }\end{array}$ & $2 \mathrm{CH}_{3}\left(\mathrm{CH}_{2}\right)_{2} \mathrm{COOH}+2 \mathrm{CH}_{2} \mathrm{O}+\mathrm{CH}_{2} \mathrm{OH} \rightarrow 3 \mathrm{CO}_{2}$ \\
& $2 \mathrm{CH}_{3} \mathrm{CH}_{2} \mathrm{OH}+\mathrm{CO}_{2} \rightarrow \mathrm{CH}_{4}+$ \\
\hline Methanobacterium suboxydans & $2 \mathrm{CH}_{3} \mathrm{COOH}_{3} \mathrm{COCH}_{3}+\mathrm{H}_{2} \mathrm{O} \rightarrow 2 \mathrm{CH}_{4}+\mathrm{CO}_{2}$ \\
\hline
\end{tabular}

Composting: Ghaly and Alkoaik (2006) and Davis et al. (1991) defined composting as the artificially accelerated decomposition of heterogeneous organic matter by a mixed aerobic microbial population in a warm moist environment. The composting process involves a biochemical transformation of organic matter during which the insoluble substances are decomposed into water soluble components, which are subsequently metabolised by micro-organisms giving off carbon dioxide and water (Ghaly et al., 2006; Levi-Minzi et al., 1992). During the composting process considerable reductions in volume and mass of the material occur. The composting process can be considered completed when the temperature of the mass has reached a peak and started to decline. According to Haug (1980), stabilization is sufficient when the rate of oxygen consumption is reduced to the point that anaerobic or odorous conditions are not produced to such an extent that they interfere with the storage and end use of the product. The key to establishing an efficient composting process is in providing all the essential nutrients for the microorganisms as well as suitable environmental conditions. Temperature, $\mathrm{pH}$, micronutrient balance, moisture aeration and residence time are among the factors affecting the quality of the compost (Makaly Biey et al., 2000). However, the temperature of the composting material is an indicator of the level of microbial activity, the higher the temperature, the higher the microbial activity in the composting mass (Ghaly and Alkoaik, 2006).

According to Ghaly et al. (2006), there are four distinct phases in the composting process Fig. 3. A mesophilic phase, (b) thermophilic phase, (c) temperature decline phase and (d) cellulose decomposition phase.

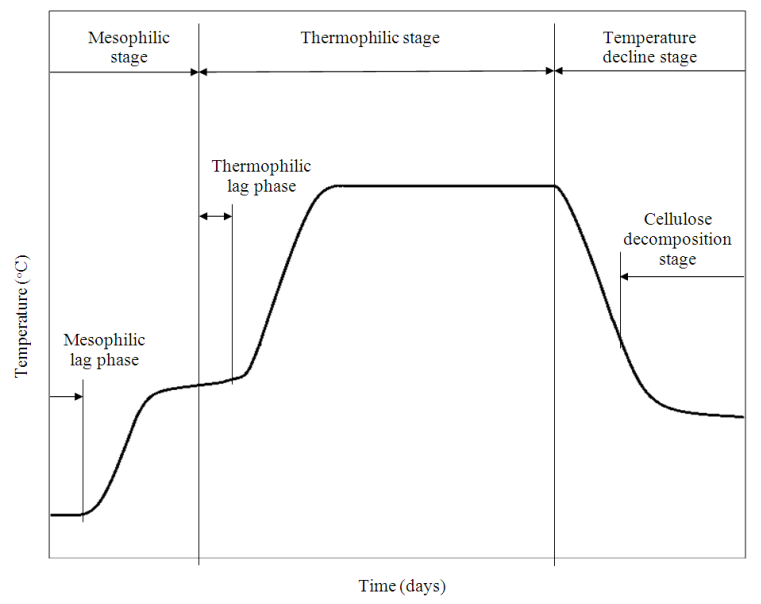

Fig. 3: Typical temperature curve of a composting process 


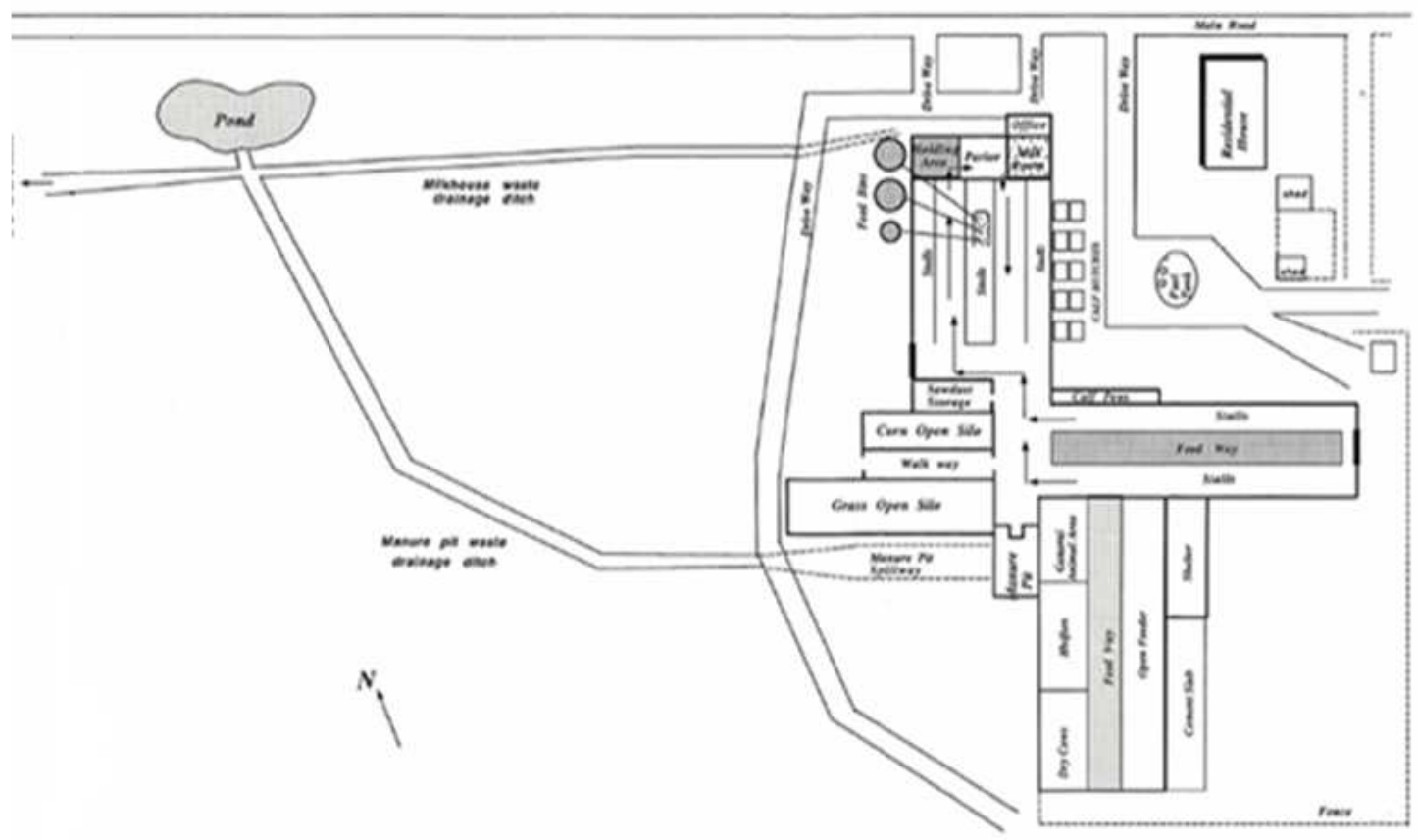

Fig. 4:Farm general layout with the waste drainage ditches

The mesophilic phase is characterised by the presence of mesophilic organisms whereby the temperature of the composting material rises from the initial starting temperature to $35^{\circ} \mathrm{C}$. In the second phase, thermophilic micro-organisms are predominant within a temperature range from of $45-70^{\circ} \mathrm{C}$. The third phase is characterised by a temperature decline reaching the ambient temperature and is associated with an upsurge of actinomycetes and fungi. In the fourth stage of the process, the highcellulosic materials (such as paper and straw) are decomposed by fungi. Plant and animal pathogens and weed seed, are destroyed during the thermophilic phase (Rubio-Loza and Noyola, 2009; Forster-Carneiro et al., 2008; Ghaly and Alkoaik, 2006; Ghaly et al., 2006).

\section{APPROACH TO FARM SUSTAINABILITY}

The aim of this research was to make a medium size dairy farm economically and environmentally sustainable through: (a) development of an anaerobic digestion/composting facility that can convert the waste into biofuels and organic fertilizer and (b) elimination of existing environmental and safety problems associated with current waste disposal method.

In the existing farm layout Fig. 4, an underground PVC drainpipe (exiting the milking parlor) transported the milkhouse waste effluent under the west-facing main road to a ditch and finally to the main fire pond. Also, the existing solid manure storage facility has a manure pit spill-way that runs westward under the main roadway, across the grazing field and slowly turns northward and connects with the milkhouse waste drainage ditch. In the new farm layout Fig. 5, both the milkhouse waste drainage ditch and the manure pit waste drainage ditch were eliminated as both effluents have been incorporated into the integrated farm waste management system.

Figure 6 shows the proposed anaerobic digestion/composting system as an integral part of the farm management system. A complete analyse of the solids produced on the farm and their uses are shown in Fig. 7. Instead of using the high solid manure (collected from the barn as it is) in the anaerobic digester, a solid-liquid separator was developed and used to separate the coarse solids from the liquid portion. The coarse solids, which are of no benefit to the anaerobic digestion process because of their long term digestibility (longer than the retention time of the digester), were composted and used on the farm as an organic fertilizer and the liquid was used in the anaerobic digester for production of biogas. Separating and composting the solids are steps towards achieving the economic and environmental sustainability of the farm through the production of value added products (biogas and compost), low ammonia emissions and complete recycling of water. The solids are sanitized (destruction of pathogenic microorganisms) through the composting process and the compost can be spread on land without risks of ammonia volatilization and spread of diseases. 


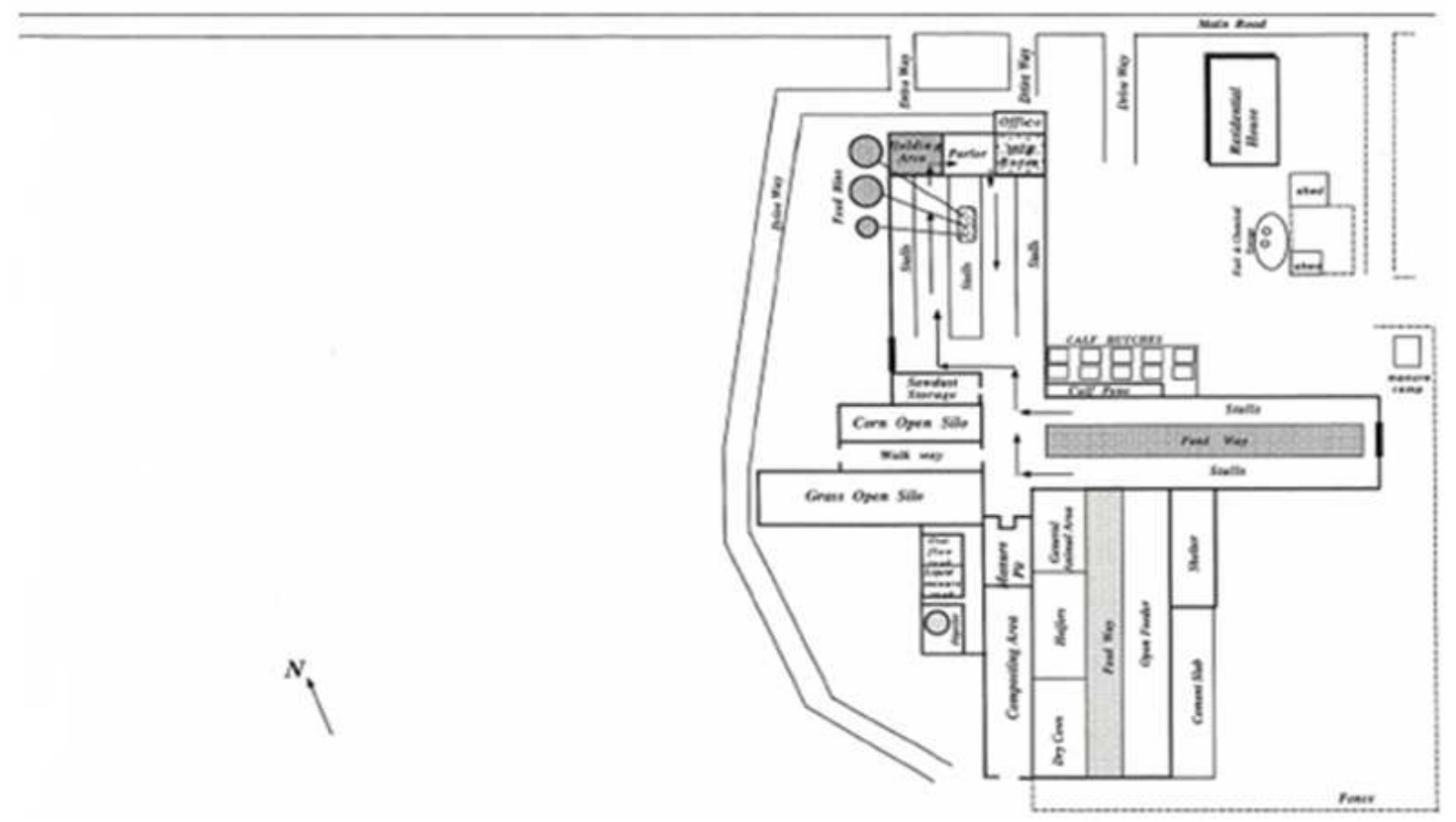

Fig. 5: New farm layout

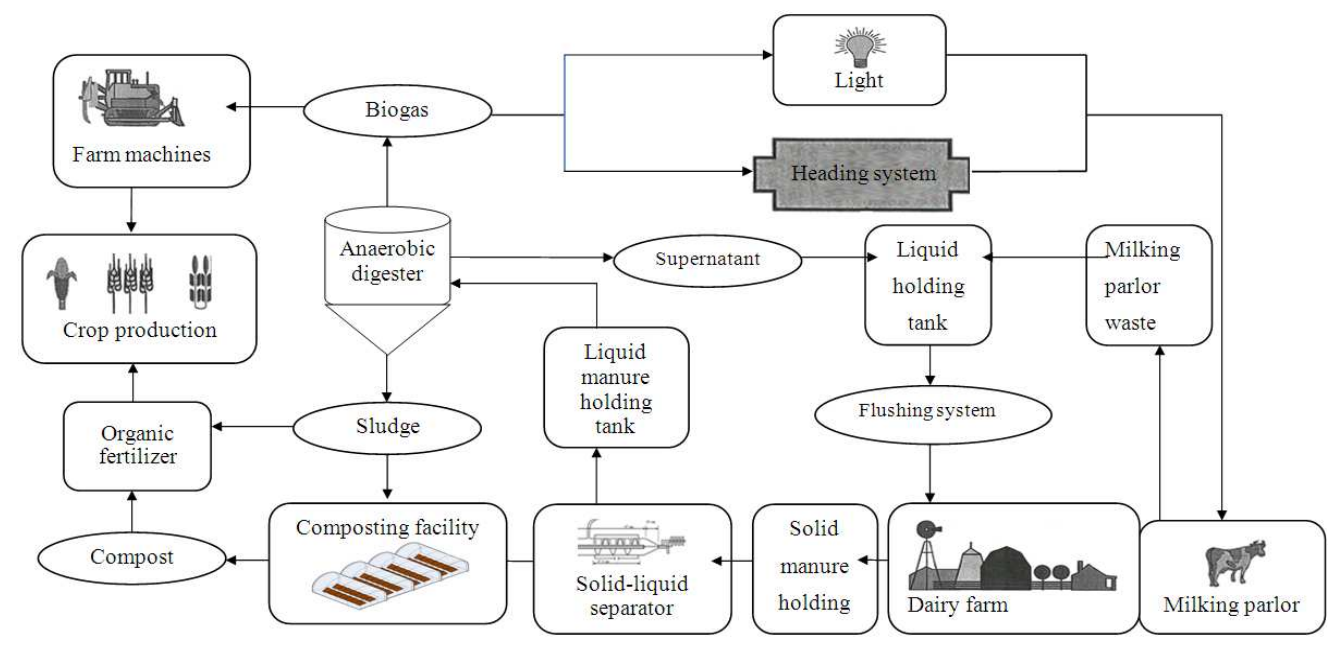

Fig. 6: A diagram showing the proposed anaerobic digestion/composting system as an integral part of the farm management

Manure storage facilities: The plan for the raw manure holding tank, press liquid manure holding tank and digester supernatant holding tank is shown in Fig. 8. The length, width and height of the raw manure holding tank are 1620,1230 and $180 \mathrm{~cm}$, respectively. A $20 \mathrm{~cm}$ thick steel reinforced concrete floor was poured on the top of four $25.4 \mathrm{~cm}$ thick steel reinforced concrete foundation walls. A sump pit area was constructed in the floor area close to the composting facility.
The length, width and height of the press liquid manure holding tank and the digester supernatant holding tank are 540, 540 and $360 \mathrm{~cm}$, respectively. A $20 \mathrm{~cm}$ thickness steel reinforced concrete slab was poured on the top of four $25.4 \mathrm{~cm}$ thick steel reinforced foundation walls. A sump pit was constructed in the center of the floor $(60 \mathrm{~cm}$ in length, $60 \mathrm{~cm}$ in width and $60 \mathrm{~cm}$ in depth). Four reinforced concrete walls of 122 $\mathrm{cm}$ height were poured above the floor. The top cover was made of $20 \mathrm{~cm}$ thick steel reinforced concrete. 
Am. J. Agri. \& Biol. Sci., 7 (1): 1-16, 2012

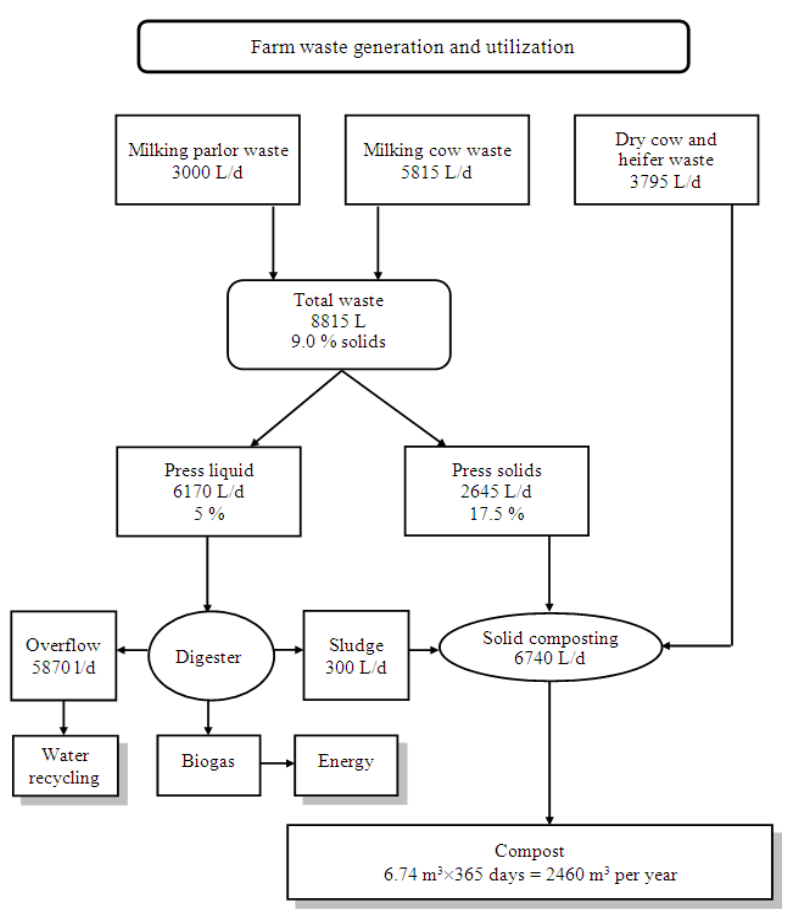

Fig. 7: Farm waste generation and utilization

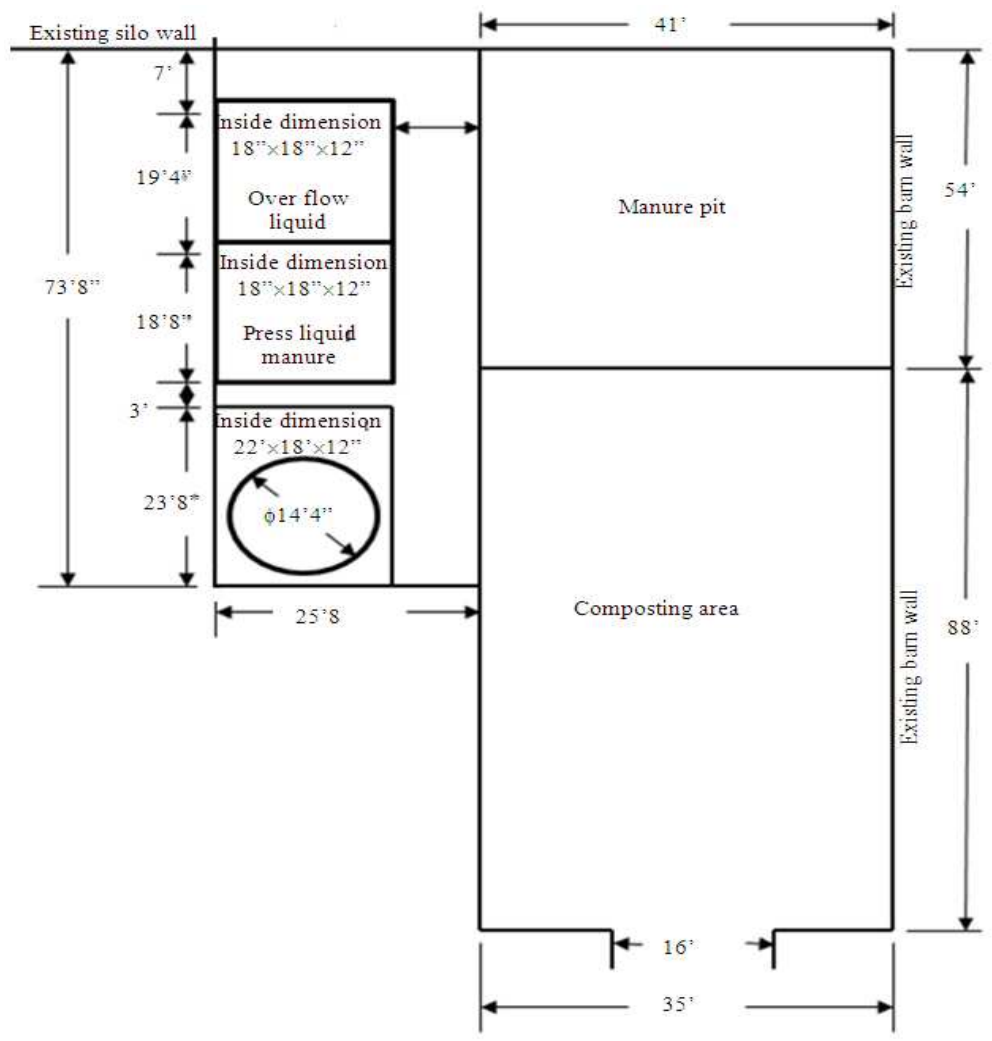

Fig. 8: The manure pit, composting area, digester, overflow tank and liquid manure tank 
Am. J. Agri. \& Biol. Sci., 7 (1): 1-16, 2012

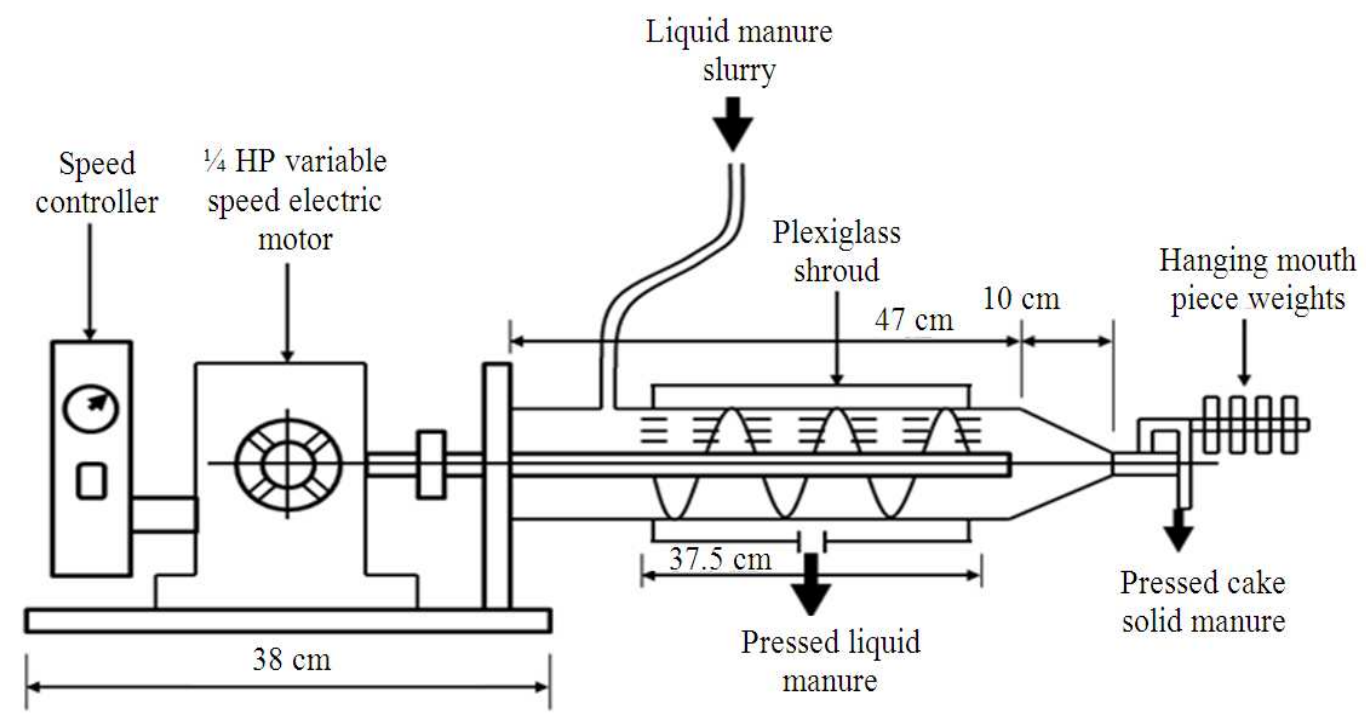

Fig. 9: Laboratory-scale solid-liquid manure separator

The outside and inside stud walls of the solid manure holding tank, press liquid holding tank and supernatant holding tank were constructed from $5 \times 25$ $\mathrm{cm}$ rough cut spruce lumber. The walls were covered with $10 \times 20 \mathrm{~cm}$ painted steel panels that were glueseamed sealed and grommeted. Galvanized sheet metal screws were used to attach each panel to the wall studs. Upon completion of the walls, the structure was enclosed using farm-grade galvanized and painted roof steel panels $(10 \times 20 \mathrm{~cm})$ that were glue-seamed sealed and grommeted. Galvanized sheet metal screws were used to attach each panel to the roof trusses.

Solid/Liquid Manure Separator: First, a laboratory scale solid-liquid manure separator was constructed of four components Fig. 9. The first component is the screw press auger which consisted of an aluminum shaft of $55 \mathrm{~cm}$ in length to which aluminum flight having a pitch of $5 \mathrm{~cm}$ was welded to a length of 47 $\mathrm{cm}$. The second component is the screen which consisted of a plexiglass cylinder of $12 \mathrm{~cm}$ diameter, 91 $\mathrm{cm}$ length and a slot width of $1 \mathrm{~mm}$. The third component is the mouthpiece (or pressed solids exit area) which was constructed of welded aluminum cone of $10 \mathrm{~cm}$ length and it has 4 hanging weights, each weighing $17.2 \mathrm{~g}$. The fourth component is the drive system made of electric $1 / 4 \mathrm{hp}$ variable speed motor (115 Volt). The separator is supported by a steel base (38 $\mathrm{cm}$ in length and $20 \mathrm{~cm}$ in width). Experiments were carried out using the laboratory scale solid-liquid separator to establish the optimum design parameters for the field scale solid-liquid separator. The laboratory scale solid-liquid separator was used to establish the design parameters for a field scale solid-liquid separator.

The field scale solid-liquid separator and supporting structure Fig. 10 were constructed from 316 stainless steel. The separator's total weight is approximately $550 \mathrm{~kg}$ and the total length is $207 \mathrm{~cm}$. The separator was held on square legs with a height of $97.5 \mathrm{~cm}$. It has a $5.3 \mathrm{hp}(4 \mathrm{~kW})$ gear motor (dual voltage) and a $2 \mathrm{hp}(0.15 \mathrm{~kW})$ vibrator (dual voltage). The screen was made of a stainless steel cylinder with $26 \mathrm{~cm}$ diameter and a slot width of $1 \mathrm{~mm}$. The screw press auger has a length of $80 \mathrm{~cm}$ and the flight pitch of $20 \mathrm{~cm}$. The mouthpiece is $48.3 \mathrm{~cm}$ in length and has 4 hanging weights, each $1 \mathrm{~kg}$. The electrical control pane 1 box was designed for outdoor use and manual operation. The power requirement is standard 220 volt 3 -phase $60-\mathrm{Hz}$. The auger drive motor is fused with starter protection. The power consumption of the various components are: $3-5.5 \mathrm{~kW}$ for the gear motor is, 3-6 kW (8 hp) for the influent pump, 3-6 kW (8 hp) for the effluent pump and $3-6 \mathrm{~kW}(8 \mathrm{hp})$ for the agitator.

Anaerobic digester: The anaerobic digester was specially designed to produce biogas as a fuel, sludge for use as an organic fertilizer and a partially purified supernatant (clearwater) for cleaning the barn thereby eliminating the need for disposal. The size of the anaerobic digester and hydraulic retention time calculations are shown in Fig. 11. 


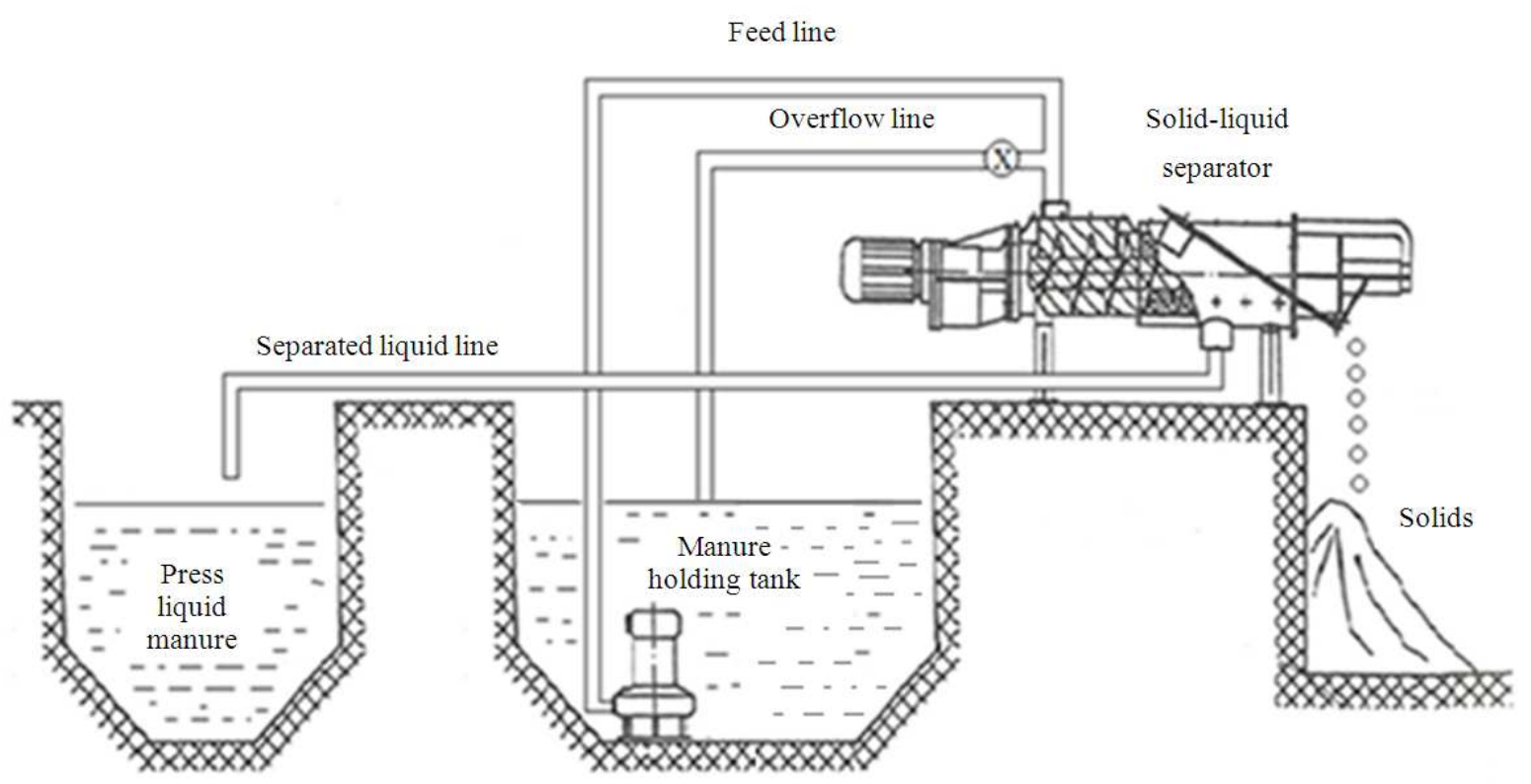

Fig. 10: Principle operation of the solid/liquid separator

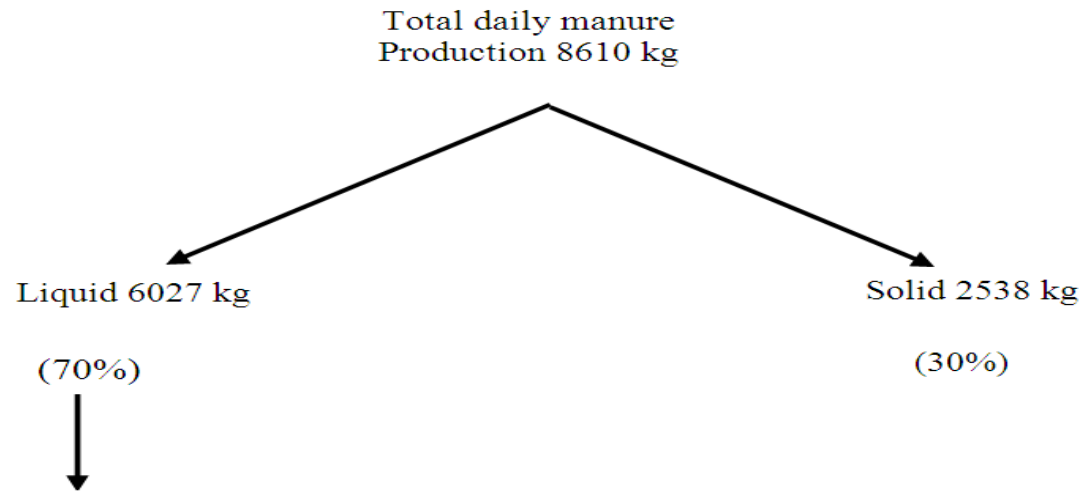

Total solids $=6 \%$

Volatile solids $=5 \%$

1. At a $5 \%$ volatile solid content, the daily volatile solids yield is $300 \mathrm{~kg}$

2. At a loading rate of $3.0 \mathrm{~kg} \mathrm{VS} / \mathrm{m}^{3} / \mathrm{day}$, the minimum volume of the digester is $100 \mathrm{~m}^{3}$

3. At daily liquid manure production of $6.027 \mathrm{~m}^{3}$, the minimum retention time is 16.72 days

4. A system of $100 \mathrm{~m}^{3}$ capacity operating at a 20 day hydraulic retention time was designed

Fig. 11: Size calculation data for the anaerobic digester

The position of the anaerobic digester within the foundation and the locations of the inlet, outlet, recirculation line and the sludge outlet are shown in Fig. 12.

The digester was constructed of plate steel of 1.27 and $0.78 \mathrm{~cm}$ thickness for the digester shell and plate steel of $0.78 \mathrm{~cm}$ and $0.94 \mathrm{~cm}$ for the bottom and top conical sections, respectively. The overall height of the digester is $884 \mathrm{~cm}$ and the digester diameter is $427 \mathrm{~cm}$.
The digester is supported using four reinforced steel legs of $20.32 \mathrm{~cm}$ diameter, schedule 40 pipe of 274 $\mathrm{cm}$ in height. The length, width and height of the digester foundation were 660,540 and $360 \mathrm{~cm}$, respectively. A set of footings were poured using reinforced concrete. A steel reinforced, concrete slab of $40 \mathrm{~cm}$ thickness was poured on the top of four $25.4 \mathrm{~cm}$ thick steel reinforced foundation walls and four walls were poured above the floor. 
Am. J. Agri. \& Biol. Sci., 7 (1): 1-16, 2012

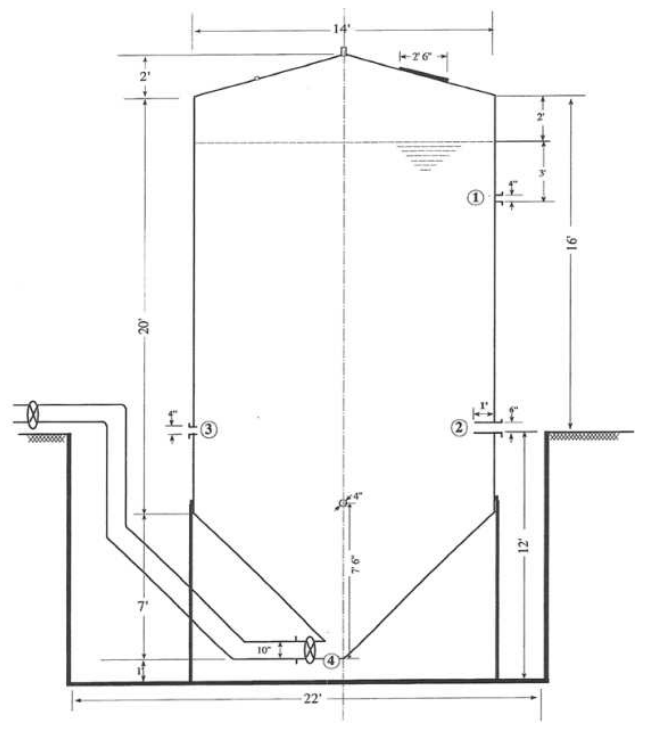

Fig. 12: Anaerobic digester

Table 5: Characteristics of the seed sludge

\begin{tabular}{ll}
\hline Parameter & Mean Value $^{1}$ \\
\hline Total solids $(\mathrm{g} / \mathrm{L})$ & 15.42 \\
Total volatile solids $(\mathrm{g} / \mathrm{L})$ & 9.640 \\
(\% of total solids) & 62.50 \\
Total fixed solids $(\mathrm{g} / \mathrm{L})$ & 5.780 \\
Total suspended solids $(\mathrm{g} / \mathrm{L})$ & 6.500 \\
Volatile suspended solids $(\mathrm{g} / \mathrm{L})$ & 2.500 \\
Fixed suspended solids $(\mathrm{g} / \mathrm{L})$ & 4.000 \\
Total COD $(\mathrm{g} / \mathrm{L})$ & 16.09 \\
Soluble COD $(\mathrm{g} / \mathrm{L})$ & 4.720 \\
Total kjeldahl nitrogen $(\mathrm{g} / \mathrm{L})$ & 1.090 \\
Ammonium nitrogen $(\mathrm{g} / \mathrm{L})$ & 0.800 \\
\hline
\end{tabular}

${ }^{1}$ Each mean represents an average of five samples

The walls of the anaerobic digester room were constructed of $5 \times 25 \mathrm{~cm}$ rough cut spruce lumber and covered with $5 \times 25 \mathrm{~cm}$ painted steel panels that were glue-seamed sealed and grommeted.

Galvanized sheet metal screws were used to attach each panel to the wall studs. The anaerobic digester was $10 \mathrm{~m}$ in height and the roof of this room was constructed on the top of $420 \mathrm{~cm}$ high walls. The roof was made of farm-grade glavanized and painted steel panels $(5 \times 25$ $\mathrm{cm})$ that were glue-seamed sealed and grommted. Galvanized sheet metal screws were used to attach each panel to the roof trusses.

Composting facility: The length and width of the compost facility were 2640 and $1230 \mathrm{~cm}$, respectively. A slab floor of $20 \mathrm{~cm}$ thick steel reinforced concrete was poured on the top of four $25.4 \mathrm{~cm}$ thick steel reinforced walls. Four walls of $122 \mathrm{~cm}$ in height were poured above the floor to support the wood structure. The walls of the composting facility were constructed of $5 \times 25 \mathrm{~cm}$ rough cut spruce lumber and covered with $10 \times 20 \mathrm{~cm}$ painted steel panels that were glue-seamed sealed and grommeted. Galvanized sheet metal screws were used to attach each panel to the wall studs. The roof was made of farm-grade galvanized and painted steel panels $10 \times 20 \mathrm{~cm}$ that were glue-seamed sealed and grommted. Galvanized sheet metal screws were used to attach each panel to the roof trusses.

\section{TESTING METHODOLOGY}

Start-up of anaerobic digester: The anaerobic digestion process requires an active population of a very selective type of microorganism which has a relatively slow growth rate and high sensitivity to changes in environmental conditions. The time required for active digestion to begin is reduced when sludge from a successfully operating digester is used as seed (Ghaly and Echigue, 1993). With seeding, a new digester can be in operation within a few weeks. Therefore, the anaerobic digester was started by adding $5000 \mathrm{~L}$ of actively digesting sewage sludge obtained from a commercial anaerobic digester operated at $35^{\circ} \mathrm{C}$. This digester is a part of the treatment facilitie $\mathrm{s}$ at the

Mill Cove Municipal Wastewater Treatment Plant located at Bedford, Nova Scotia, Canada. Table 5 shows the characteristics of the seed sludge. The addition of the seed sludge was followed by the addition of $5000 \mathrm{~L}$ of liquid dairy manure.

The digesters were left without further feeding for $48 \mathrm{~h}$ at an average environmental temperature of $25^{\circ} \mathrm{C}$. The digester was then fed on a daily basis at a Hydraulic Retention Time (HRT) of 20 days. The startup period was concluded after a period of 30 days.

Composting operation: The separated solids were mixed with fresh municipal solid waste compost (Miller Compost Corporation, Dartmouth, Nova Scotia) at a ratio of 1:10 (compost to solid manure). The $\mathrm{C}: \mathrm{N}$ ratio and moisture content were adjusted to $30: 1$ and $60 \%$ using urea $\left(\mathrm{CO}\left(\mathrm{NH}_{2}\right)_{2}\right)$ and water, respectively. The mixture was divided into windrows of $250 \mathrm{~cm}$ wide. The windrows were mixed with front loader once a day starting from the third day. The temperature was monitored on a daily basis for one month. Samples were taken from the windrows every five days for $\mathrm{pH}$, $\mathrm{C}: \mathrm{N}$, moisture content, total carbon, TKN and solids analyses. The maturity of the final compost was evaluated by measuring the $\mathrm{pH}, \mathrm{CO}_{2}$ evolution, $\mathrm{C}: \mathrm{N}$ ratio and germination index. 
Sampling and analysis: Following the initial start up period, monitoring of the biogas production and the effluent characteristics were started on day 30 (from the start). A steady state was construed to have been achieved when a uniform gas production and/or uniform effluent quality were achieved. Liquid samples of the effluent were taken daily for solids, Chemical Oxygen Demand (COD), nitrogen and volatile fatty acid analyses. Gas samples were taken from the head space of the reactors using syringes for biogas analysis.

The solids and COD analyses were performed according to the procedures described in the Standard Methods for Examination of Water and Wastewater (APHA, 1985). The nitrogen analyses were performed using a Tecator Kjeltec Auto Analyzer (Model 1030, Tecator, Paris, France).

The individual volatile acids $\left(\mathrm{C}_{2}-\mathrm{C}_{7}\right)$ contained were determined using a Hewlett-Packard gas chromatograph (Model 5890 series II, Mississauga, Ontario, Canada) equipped with an HP 76734A automatic injector. Extraction of the VFA was carried out by acidifying $3.0 \mathrm{~mL}$ of each of the manure samples using $0.1 \mathrm{~mL} 30 \%$ sulphuric acid. The acidified samples were well mixed and centrifuged at $7000 \mathrm{rpm}$ for $20 \mathrm{M}$. $2.0 \mathrm{~mL}$ of the supernatants were decanted and an equal amount of diethyl ether was added. The mixtures were well shaken and then centrifuged at $5000 \mathrm{rpm}$ for $5 \mathrm{M}$ to break down the emulsion layer. The upper layers which consisted of diethyl ether were removed for analysis. Volatile acids were, also, extracted from a volatile acid standard mixture (No 4-6975, SupelCo, Oakville, Ontario, Canada) using diethyl ether. The chromatograph was calibrated by injecting $1.0 \mathrm{~mL}$ of the extracted standard VFA mixture into the $25 \times 0.2 \mathrm{~mm}$ capillary column of the liquid chromatograph whose film thickness is 0.33 $\mathrm{mm} .1 .0 \mathrm{~mL}$ of the extracted samples was injected into the column. A split ratio of 1:5 was applied. The column temperature was first maintained at $60^{\circ} \mathrm{C}$ for 3 $\mathrm{M}$ and then increased at a rate of $10^{\circ} \mathrm{C} \mathrm{min}^{-1}$ until a temperature of $150^{\circ} \mathrm{C}$ was attained.

The column temperature was maintained at $150^{\circ} \mathrm{C}$ for $2 \mathrm{M}$. The injector was set at $180^{\circ} \mathrm{C}$ while the flame ionization detector was set at $250^{\circ} \mathrm{C}$. The carrier gas was helium at a flow rate of $1.2 \mathrm{~mL} \mathrm{~min}^{-1}$.

The composition of biogas was determined using a gas chromatograph (Model HP 5980A, Hewlett Packard, Mississauga, Ontario, Canada). Samples of $0.1 \mathrm{~mL}$ were taken from the gas collected in the sampling tubes using a gas tight locked syringe. The samples were injected into $152.4 \times 3.2 \mathrm{~mm}(6$ in $\times 1 / 8$ in) OD porapak Q stainless steel column of the gas chromatograph which is connected in a series bypass arrangement with a $152.4 \times 3.2 \mathrm{~mm}$ OD molecular sieve 5 A 60180 stainless steel column. The switch valve of the gas chromatograph was adjusted to permit the molecular sieve column to store nitrogen, methane and carbon monoxide until the elution of the $\mathrm{CO}_{2}, \mathrm{C}_{2} \mathrm{H}_{2}$ and $\mathrm{C}_{6} \mathrm{H}_{6}$ through the porapak $\mathrm{Q}$ stainless steel column. The column was maintained at $45^{\circ} \mathrm{C}$ with helium as the carrier gas at $30 \mathrm{~mL} \mathrm{~min}{ }^{-1}$. The injector was set at $150^{\circ} \mathrm{C}$ while the thermal conductivity detector was set at $250^{\circ} \mathrm{C}$.

\section{RESULTS}

Digester performance: The diurnal fluctuation in temperature, $\mathrm{pH}, \mathrm{COD}$, total solids, nitrogen, fatty acids are shown in Fig. 13.

Temperature and $\mathbf{p H}$ : the average ambient temperature was $21^{\circ} \mathrm{C}$. The temperature of the digester room fluctuated between $14^{\circ} \mathrm{C}$ during the night and $28^{\circ} \mathrm{C}$ during the day. This was due to the variation of outdoor temperatures as shown in Fig. 13a. The minimum and maximum temperatures of the digester were 18 and $24^{\circ} \mathrm{C}$, respectively. The digester temperature amplitude was $2^{\circ} \mathrm{C}$. Relative to the room temperature, the digester minimum and maximum temperatures lagged $3 \mathrm{~h}$ behind those of the room temperature. This was due to the significant difference between the density of the air surrounding the digester and that of the liquid medium in the digester. The reactor $\mathrm{pH}$ was not affected by the fluctuation in reactor temperature and remained constant at 6.8.

COD: The diurnal variations of the effluent total and soluble chemical oxygen demand (TCOD and SCOD) are presented in Fig. 13b. The TCOD cycle was approximately $12 \mathrm{~h}$ out of phase with the digester temperature. However, the SCOD cycle was only $4 \mathrm{~h}$ out of phase with the digester temperature. The influent TCOD and SCOD were 98.80 and $27.90 \mathrm{~g} \mathrm{~L}^{-1}$ and the effluent TCOD and SCOD were 37.64 and $3.66 \mathrm{~g} \mathrm{~L}^{-1}$, respectively. The reduction in SCOD (87\%) was higher than the reduction in TCOD (62\%) indicating the conversion of the soluble organic matter to microbial cells.

Total solids: The diurnal variations in the effluent total, volatile and fixed solids are shown in Fig. 13c. The fixed solids were in phase with the digester temperature but the total and volatile solids were out of phase with the digester temperature by $3 \mathrm{~h}$. The influent total, volatile and fixed solids were $64.25,50.26$ and $13.99 \mathrm{~g}$ $\mathrm{L}^{-1}$ and the effluent total volatile and fixed solids were $23.3,6.70$ and $6.6 \mathrm{~g} \mathrm{~L}^{-1}$, respectively. 
Am. J ri. \& Biol. Sci., 7 (1): 1-16, 2012

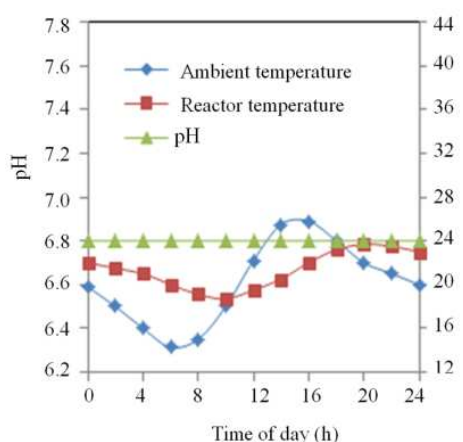

(a)

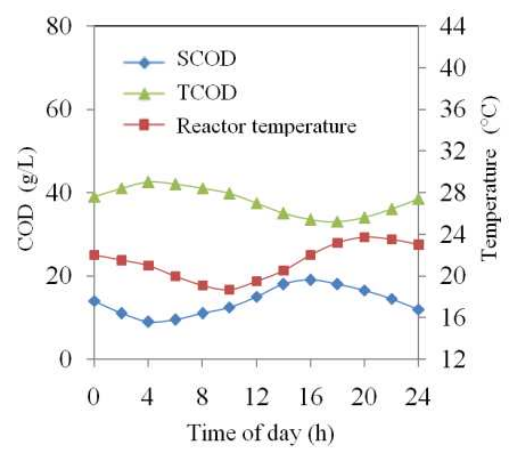

(b)

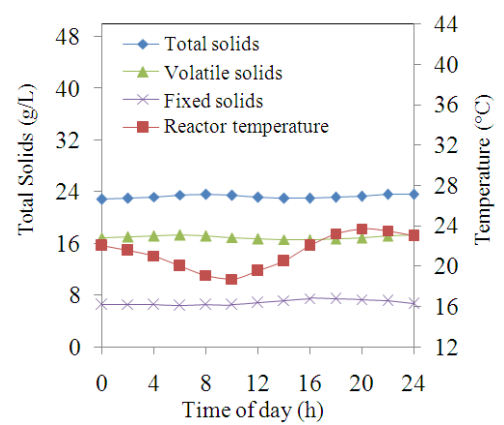

(c)

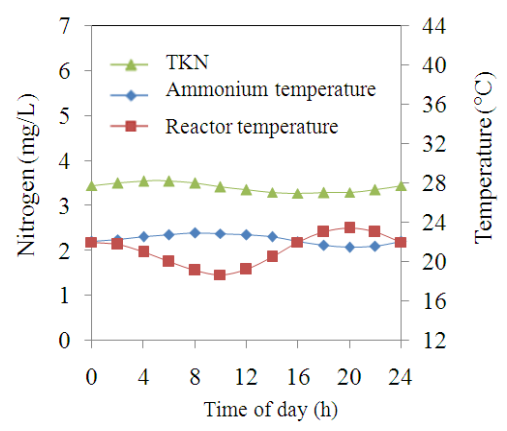

(d)

Fig. 13: Diurnal variations in the digester parameters Temperature and $\mathrm{pH}$. COD content. Solid content. Nitrogen content
Table 6: Volatile fatty acids concentration

\begin{tabular}{lcc}
\hline & Acid concentration $(\mathrm{mg} / \mathrm{L})$ \\
Volatile acid & Digester & Raw manure \\
\hline Acetic & 5.300 & 1548.4 \\
Propionic & 3.600 & 283.50 \\
i-Butyric & 1.300 & 44.500 \\
n-Butyric & 1.300 & 60.500 \\
i-Valeric & 2.000 & 40.200 \\
n-Valeric & 2.200 & 21.000 \\
i-Caproic & 1.300 & 7.0000 \\
n-Caproic & 0.700 & 11.300 \\
Heptanoic & 0.010 & 37.100 \\
Total as acetic acid & 13.500 & 1913.0 \\
\hline
\end{tabular}

Reductions of $63.74,66.77$ and $52.82 \%$ in the total, volatile and fixed solids were achieved, respectively. The reductions in the fixed solids could be due to the precipitation of some elements in the form of phosphate and samples.

Nitrogen: The diurnal changes in the Total Kjeldhal Nitrogen (TKN) and ammonium nitrogen $\left(\mathrm{NH}_{4}-\mathrm{N}\right)$ are shown in Fig. 13d. The TKN on $\mathrm{NH}_{4}-\mathrm{N}$ were out of phase with the digester temperature by 8 and 14 days, respectively. The initial $\mathrm{TKN}$ and $\mathrm{NH}_{4}-\mathrm{N}$ in the influent were 5.84 and $1.75 \mathrm{~g} \mathrm{~L}^{-1}$, respectively. The TKN was reduced to 3.2 (45\% reduction) and the $\mathrm{NH}_{4}-\mathrm{N}$ was increased to $2.2 \mathrm{~g} \mathrm{~L}^{-1}$ (25.7\% increase).

Volatile fatty acids: The concentrations of Volatile Fatty Acids (VFAs) in the effluent samples taken during the steady state conditions are shown in Table 6 . The indentified volatile acids include: acetic, propionic, iso-butyric, iso-valeric, valeric, iso-caproic, caproic and heptanoic acids. Among the VFAs, acetic acid had the highest concentration followed by propionic acid in both the raw manure (influent) and digester (effluent).

Biogas production: Figure 14 shows the daily biogas production from the start of the seeding of the digester. The biogas production rate rose steadily reaching a maximum value of $135.3 \mathrm{~m}^{3} \mathrm{~d}^{-1}$ on day 9 and then remained fairly steady. There was no clearly noticeable Relationship between the diurnal temperature and the diurnal biogas production rate. The percentage of $\mathrm{CH}_{4}$ varied from 69-73\% and that of $\mathrm{CO}_{2}$ varied from 26-30 $\%$. The other gases $\left(\mathrm{N}_{2}, \mathrm{H}_{2} \mathrm{~S}\right)$ made approximately $1 \%$.

Composting performance: The initial and final values of temperature, moisture content, volatile solids, total carbon, TKN and C: $\mathrm{N}$ ratio as well as the values of the maturity and stability parameters $\left(\mathrm{pH}, \mathrm{CO}_{2} \mathrm{c} / \mathrm{d}\right.$ and $\left.\mathrm{GI}\right)$ are presented in Table 7. 
Am. J. Agri. \& Biol. Sci., 7 (1): 1-16, 2012

Table 7: Composting Parameters

\begin{tabular}{llll}
\hline Parameter & Initial & Final & Reduction $(\%)$ \\
\hline Temperature $\left({ }^{\circ} \mathrm{C}\right)$ & 24.00 & 24.00 & \\
Moisture content $(\%)$ & 60.66 & 52.82 & 12.9 \\
Volatile Solids $(\mathrm{g} \mathrm{VS} / \mathrm{kg})$ & 87200 & 5070 & 32.7 \\
Total Carbon $(\mathrm{g} \mathrm{C} / \mathrm{kg})$ & 43700 & 4060 & 7.10 \\
TKN $(\%)$ & 14.600 & 14.10 & 12.4 \\
$\mathrm{C}:$ N Ratio & $29.9: 1$ & $26.2: 1$ & \\
Maturity and stability & & & \\
pH & & 5.80 & \\
$\mathrm{CO}_{2}$ c/d & & 5.70 & \\
$\mathrm{GI}(\%)$ & & 92.0 & \\
\hline
\end{tabular}

The maximum temperature was 39.1 and was reached after $9 \mathrm{~d}$ and lasted for $12 \mathrm{~d}$

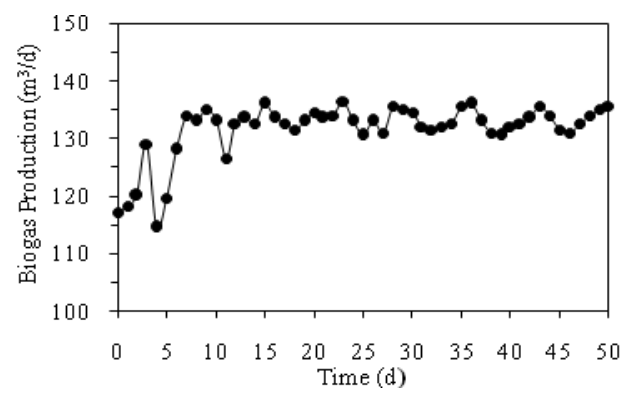

Fig. 14: Daily biogas production during the steady state

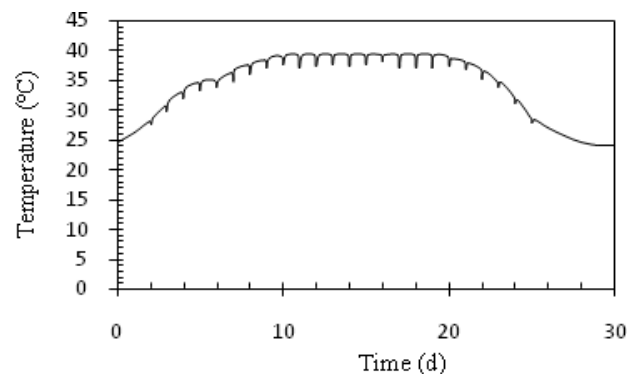

Fig. 15: The temperature profile of the composting process

Temperature: The initial temperature was $24^{\circ} \mathrm{C}$ which increased due to the heat produced by microbial activity to $39.1^{\circ} \mathrm{C}$ over $9 \mathrm{~d}$ and lasted $12 \mathrm{~d}$ before declining back to the ambient temperature Fig. 15. Mixing of the windrows caused fluctuation in the temperature. A temperature higher than $35^{\circ} \mathrm{C}$ (thermophelic stage) lasted for $19 \mathrm{~d}$ (from day 3 to day 22). Lag phases were clearly identified during the mesophelic and thermophilic phases.

Moisture content: The initial moisture content of the mixture was adjusted to approximately $60(60.66 \%+/-$ $1.27 \%)$. The final moisture content was $43.82+/-$ $1.17 \%$. The reduction in moisture content was $27.76 \%$ this was due to the evaporation of water and loss of vapour due to mixing.
Table 8: Potential fertilizer and energy savings

\begin{tabular}{lll} 
Fertilizer & & \\
\hline $\begin{array}{l}\text { Compost production } \\
\text { Sludge production }\end{array}$ & 926 & ton/year \\
Total organic fertilizer & 40 & ton/year \\
Nutrient availability in organic fertilizer & 1066 & ton/year \\
Nitrogen & 5.9 & $\mathrm{~kg} / \mathrm{ton}$ \\
Phospohrous & 1.4 & $\mathrm{~kg} / \mathrm{ton}$ \\
Potassium & 4.7 & $\mathrm{~kg} / \mathrm{ton}$ \\
Commercial fertilizer replacement & 6289 & $\mathrm{~kg} /$ year \\
Benefits from fertilizer replacement & $\$ 17,925$ & $\mathrm{per}$ year \\
Energy & & \\
Biogas production & 49275 & $\mathrm{~m}^{3} /$ year \\
Energy production & 1231875 & $\mathrm{MJ} /$ year \\
& 342461 & $\mathrm{kWh} / \mathrm{year}$ \\
Benefit from energy replacement & $\$ 20,547$ & per year \\
Total savings & $\$ 38,472$ & per year \\
\hline
\end{tabular}

$\mathrm{M}^{3}$ biogas $=25 \mathrm{MJ}, \mathrm{MJ}=0.278 \mathrm{kWh}, \mathrm{kWh}=\$ 0.06$

Volatile solids: The initial volatile solids were $872 \mathrm{~g}$ VS $\mathrm{kg}^{-1} \mathrm{DM}$ which was reduced to $507 \mathrm{~g} \mathrm{VS} \mathrm{kg}^{-1} \mathrm{DM}$ by the end of the process. The reduction in volatile was $32.7 \%$.

Total carbon: The initial concentration of the total carbon was $437 \mathrm{~g} \mathrm{C} \mathrm{kg}^{-1} \mathrm{DM}$ which decreased with time reacting $406 \mathrm{~g} \mathrm{C} \mathrm{kg}^{-1} \mathrm{DM}$. The reduction in total carbon was $7.1 \%$.

TKN: The initial and final values of the TKN were 14.6 and $14.1 \%$, respectively. The TKN reduction was $3.4 \%$.

C: $N$ ratio: The initial and finial $\mathrm{C}$ : $\mathrm{N}$ ratios were 29.9:1 and 26.2:1, respectively.

Maturity and stability: The maturity and stability compost was evaluated by determining the $\mathrm{pH}, \mathrm{CO}_{2}$ evolution rate and the Germinate Index (GI) of the final product. The $\mathrm{CO}_{2}$ is a good indication to determine the level of microbial activity and stability of compost. The germination index provides information about the phyto toxic organic substances. The lower the $\mathrm{CO}_{2}$ evolution the more stable the compost. The $\mathrm{pH}$ was 5.8 which are within the optimum range of 5-7 for mature compost. The $\mathrm{CO}_{2}$ c/d was 4.7 and the GI was $92 \%$ indicating a mature and stable final product.

\section{DISCUSSION}

The potential savings of energy and fertilizer use on the farm are presented in Table 8 . The use of dairy waste as a source of fertilizer and energy allows a small scale dairy farm to replace about $6289 \mathrm{~kg}$ of commercial fertilizers annually, which leads to a cost savings of $\$ 17925$ annually in addition to annual savings of $\$ 20547$ on energy use. The digestion of manure produced about $49275 \mathrm{~m}^{3}$ of biogas per year, yielding approximately $342461 \mathrm{kWh}$. 


\section{CONCLUSION}

A solid liquid manure separator, a farm scale anaerobic digester and a composting facility for a medium size dairy farm were designed, constructed and tested. In order to make the system economically viable under Canadian climatic conditions, the design, installation and operation of the system were based on advantages gained from the digester and composting operation as a component of the total farm management system. In addition to the biogas production from the system, benefits related to manure handling and storage, environmental quality improvement through odour control and water pollution reduction, water recycling and production of organic fertilizer were considered. The developed solid-liquid separator is an efficient solids separation system for manure with high solids content. The solids from the solid-liquid separator, have the optimal moisture content for long term storage plus a structure honeycombed with dispersed air pockets that will significantly stimulate the composting process. The digester design eliminates the agitation problem believed to be a major difficulty in the operation of mechanically mixed digesters especially with farm scale units. Mixing alone takes about $26 \%$ of the total energy input to digester. It solves the sedimentation and sludge return problem which limits the performance of the anaerobic processes while producing concentrated animal feed and organic fertilizer. The digester design helps to maintain the concentration of methane producing bacteria in the system at higher level and in active state which eliminates the need for longer retention time and larger reactor volume, thereby reducing both the operating and capital costs. It operates at low temperatures $\left(20-25^{\circ} \mathrm{C}\right)$ thereby saving on energy required to heat the system. By using the liquid portion of the manure (which contains the dissolved solids) in the anaerobic digester a smaller digester was built thereby reducing the capital and operating costs. The indoor composting facility allowed a continuous production of high quality compost at a relatively low labour cost (926 tons annually). Using dairy manure as a source of energy and fertilizer resulted in a saving of $\$ 17925$ on fertilizers and \$20 547 on energy use.

\section{ACKNOWLEDGEMENT}

This research was funded by the National Science and Engineers Council (NSERC) of Canada.

\section{REFERENCES}

Albihn, A. and B., Vinneras, 2007. Biosecurity and arable use of manure and biowaste-treatment alternatives. Livestock Sci., 112: 232-239. DOI: 10.1016/j.livsci.2007.09.015.

Almasri, M.N. and J.J., Kaluarachchi, 2004. Assessment and management of long-term nitrate pollution of ground water in agriculture-dominated watersheds. J. Hydrology. 295: 225-245. DOI: 10.1016/j.jhydrol.2004.03.013.

Anderson, B.C. and L.K. Quartermaine, 1998. Tastes and odors in kingston's municipal drinking water: A case study of the problem and appropriate solutions. J. Great Lakes Res., 24: 859-867. DOI: 10.1016/S0380-1330(98)70867-6.

APHA, 1985. Standard Methods for the Examination of Water and Wastewater. 16th (Edn.)., American Public Health Association, Washington, D.C. ISBN: 0-87553-078-8.

Arvanitoyannis, I.S. and A. Kassaveti, 2008. Dairy waste management: Treatment methods and potential uses of treated waste. Waste Manage. Food Industry. DOI: 10.1016/B978-0123736543.50016-X.

Batzias, F.A., D.K. Sidiras and E.K. Spyrou, 2005. Evaluating livestock manures for biogas production: A GIS based method. Renewable Energy, $\quad 30$ : $1161-1176 . \quad$ DOI: 10.1016/j.renene.2004.10.001.

Bot, G.P.A., 2001. Developments in indoor sustainable plant production with emphasis on energy saving. Comp. Electronics Agric., 30: 151-165. DOI: 10.1016/S0168-1699(00)00162-9.

Centner, T.J., M.E. Wetzstein and J.D. Mullen, 2006. Small livestock producers with diffuse water pollutants: Adopting a disincentive for unacceptable manure application practices. Desalination. 226: 66-71. DOI: 10.1016/j.desal.2007.01.234.

Cliver, D.O., 2009. Disinfection of animal manures, food safety and policy. Bioresource Tech., 100: 5392-5394. DOI: 10.1016/j.biortech.2009.04.038.

Dabrowski, J.M., S.K.C. Peall, A.V. Niekerk, A.J. Reinecke and J.A. Day et al., 2002. Predicting runoff-induced pesticide input in agricultural sub-catchment surface waters: linking catchment variables and contamination. Water Res., 36: 4975-4984. DOI: 10.1016/S00431354(02)00234-8.

Dammgen, U. and N.J. Hutchings, 2007. Emissions of gaseous nitrogen species from manure management: A new approach. Environ. Pollution. 154: 488-497. DOI: 10.1016/j.envpol.2007.03.017. 
Davis, C.L., S.A. Hinch, C.J. Donkin and P.J. Germishuizen, 1991. Changes in Microbial Population Numbers During the composting of Pine Bark. Bioresource Techn., 39: 85-92. ISSN: 0960-8524.

El Boushy, A.R., 1991. House-fly pupae as poultry manure converters for animal feed: A review. Bioresource Technology, 38: 45-49. DOI: 10.1016/0960-8524(91)90220-E.

El Jalil, M.H., M. Faid and M. Elyachioui, 2001. A biotechnological process for treatment and recycling poultry wastes manure as a feed ingredient. Biomass Bioenergy, 21: 301-309. DOI: 10.1016/S0961-9534(01)00040-X.

Ellis, G., I. Adatia, M. Yazdanpanah and S.K. Makela, 1998. Nitrite and nitrate analyses: A clinical biochemistry perspective. Clinical Biochemistry. 31: 195-220. DOI: 10.1016/S0009-9120(98)00015-0.

El-Mashad, H.M. and R. Zhang, 2010. Biogas production from co-digestion of dairy manure and food waste. Bioresource Techn., 101: 4021-4028. DOI: 10.1016/j.biortech.2010.01.027.

Forster-Carneiro, T., M. Perez and L.I. Romero, 2008. Thermophilic anaerobic digestion of source-sorted organic fraction of municipal solid waste. Bioresource Techn., 99: 6763-6770. DOI: 10.1016/j.biortech.2008.01.052.

Ghaly, A.E. and A. Alkoaik, 2006. Influence of dairy manure addition on the biological and thermal kinetics of composting of greenhouse tomato plant residues. Waste Manag., 28: 902-913. ISSN: 0956-053X.

Ghaly, A.E. and E.A. Echiegu, 1993. Performance evaluation of an intermittent mix anaerobic reactor operating on dairy manure. Biomass Bioenergy, 4: 185-197. ISSN: 0961-9534.

Ghaly, A.E. and R. Singh, 1991. Laboratory evaluation of the pollution potential of land applied dairy manure. Waste Manag., 11: 307-318. DOI: 10.1016/0956-053X(91)90077-I

Ghaly, A.E., 1989. Biogas production from acid cheese whey using a two stage digester. Energy Sources. 11: 237-250. ISSN: 0090-8312.

Ghaly, A.E., A. Alkoaik and A. Snow, 2006. Thermal balance of in vessel composting of tomato plant residues. Canadian Biosystem Eng., 48: 13-22. ISSN: 1496-2551.

Grady, C.P.L. and H.C. Lim, 1980. Biological Wastewater Treatment. Marcel Dekker Inc., New York, New York. ISBN: 0-8247-8919-9.

Haug, T., 1980. Compost engineering; principles and practice. Lancaster Technomic Publishing Co., Lancaster, U.K. ISBN: 0-2504-0347-1.
Imlay, J.A., 2002. How oxygen damages microbes: Oxygen tolerance and obligate anaerobiosis. Advances in Microbial Physiology. 46: 111-153. DOI: 10.1016/S0065-2911(02)46003-1.

Isaac, M. and D.P.V. Vuuren, 2009. Modeling global residential sector energy demand for heating and air conditioning in the context of climate change. Energy Policy. 37: 507-521. DOI: 10.1016/j.enpol.2008.09.051

Kuligowski, K., T.G. Poulsen, G.H. Rubaek and P. Sorensen, 2010. Plant-availability to barely of phosphorous in ash from thermally treated animal manure in comparison to other manure based materials and commercial fertilizer. Europ. J. Agronomy, 33: 293-303. DOI: 10.1016/j.eja.2010.08.003.

Levi-Minzi, R., A. Saviozzi and R. Riffaldi, 1992. Evaluating garbage compost. BioCycle: J. composting organics Recycling. 33: 75-78. ISSN: 0276-5055.

Loehr, R.C., 1984. Pollution Control for Agriculture. Academic Press, Toronto. ISBN: 0-12-455270-6.

Lunnan, A., 1997. Agriculture-based biomass energy supply-a survey of economic issues. Energy Policy. 25: 573-582. DOI: 10.1016/S0301-4215(97)00048-7.

Makaly Biey, E., H. Mortier and W. Verstraete, 2000. Nitrogen transfer from grey municipal solid waste to high quality compost. Bioresource Techn., 73: 47-52. DOI: 10.1016/S0960-8524(99)00136-4.

Marchesi, J.R., A.J. Weightman, B.A. Cragg, R.J. Parkes and J.C. Fry, 2001. Methanogen and bacterial diversity and distribution in deep gas hydrate sediments from the Cascadia Margin as revealed by $16 \mathrm{~S}$ rRNA molecular analysis. FEMS Microbiology Ecology. 34: 221-228. DOI: 10.1016/S0168-6496(00)00099-4.

Mawdsley, J.L., R.D. Bardgett, R.J. Merry, B.F., Pain and M.K. Theodorou, 1995. Pathogens in livestock waste, their potential for movement through soil and environmental pollution. Applied Soil Ecology. 2: 1-15. $\quad$ DOI: 10.1016/09291393(94)00039-A.

Melse, R.W. and M. Timmerman, 2009. Sustainable intensive livestock production demands manure and exhaust air treatment technologies. Bioresource Techn., 100: 5506-5511. DOI: 10.1016/j.biortech.2009.03.003.

Meynell, G., 1978. Notes on foxing, chlorine dioxide bleaching and pigments. The Paper Conservator. 4: 20-29. ISSN: 03094227.

Mishra, P.C. and R.K. Patel, 2007. Use of agricultural waste for the removal of nitrate-nitrogen from aqueous medium. J. Environ. Manag., 90: 519-522. DOI: 10.1016/j.jenvman.2007.12.003. 
Nguyen, T.L.T., J.E. Hermansen and L. Mogensen, 2010. Fossil energy and GHG saving potentials of pig farming in the EU. Energy Policy. 38: 25612571. DOI: 10.1016/j.enpol.2009.12.051

Ni, J.Q., J. Hendriks, C. Vinckier and J. Coenegrachts, 2000. A new concept of carbon dioxide accelerated ammonia release from liquid manure in pig house. Environ. Int., 26: 97-104. DOI: 10.1016/S01604120(00)00087-8.

Oudendag, D.A. and H.H. Luesink, 1998. The manure model: Manure, minerals ( $\mathrm{N}, \mathrm{P}$ and $\mathrm{K})$, ammonia emission, heavy metals and the use of fertiliser in Dutch agriculture. Environ. Pollution, 102: 241246. DOI: 10.1016/S0269-7491(98)80039-0.

Rubio-Loza, L.A. and A. Noyola, 2009. Two-phase (acidogenic-methanogenic) anaerobic thermophilic/mesophilic digestion system for producing class A biosolids from municipal sludge. Bioresource Techn., 101: 576-585. DOI: 10.1016/j.biortech.2009.08.066.

Sarapatka, B., 1994. Factors influencing biogas production during full-scale anaerobic fermentation of farmyard manure. Bioresource Technology, 49: 17-23. DOI: 10.1016/0960-8524(94)90168-6.
Schroder, J., 2005. Revisiting the agronomic benefits of manure: A correct assessment and exploitation of its fertilizer value spares the environment. Bioresource Techn., 96: 253-261. DOI: 10.1016/j.biortech.2004.05.015.

Shafiee, S. and E. Topal, 2007. An econometrics view of worldwide fossil fuel consumption and the role of US. Energy Policy, 36: 775-786. DOI: 10.1016/j.enpol.2007.11.002.

Shi, W., J.M. Norton, B.E. Miller and M.G. Pace, 1999. Effects of aeration and moisture during windrow composting on the nitrogen fertilizer values of dairy waste composts. Applied Soil Ecology. 11: 17-28. DOI: 10.1016/S0929-1393(98)00135-8.

Zhao, Y., N. Ren and A. Wang, 2008. Contributions of fermentative acidogenic bacteria and sulphatereducing bacteria to lactate degradation and sulphate reduction. Chemosphere. 72: 233-242. DOI: 10.1016/j.chemosphere.2008.01.046. 